Neslihan Avcı ${ }^{1}$

Müge Kunt ${ }^{2}$

\title{
Examination of Ministry of National Education's Infant and Toddler Program Regarding Early Intervention Principles
}

\author{
Abstract
}

\begin{abstract}
The earlyyears of life provide opportunities not to be missed for optimum development as a critical period in which the development is very rapid. Therefore, regarding the broad meaning of early intervention, revealing all the circumstances which can hinder developmental progress and making appropriate and supportive attempts must be among the priorities of birth to threeprograms. The purpose of this study was to qualitatively examine the Ministry of National Education's (MoNE)) Infant and Toddler Program, which was prepared as a part of the project of empowering preschool education, in terms of basic principles of early intervention and understanding about meeting needs of all children. In this regard, the following were materials of the study: Infant and Toddler Program Guidelines, Infant and Toddler Program Activity Book, Educator's Guidelines for Parent Education and Parenting Guidelines, and Health, Care and Nutrition of 0-36-Month-Old Children Booklet. The study materials were first examined in terms of working with the family and empowering family environment, partnership, individualization, developmentally appropriate practice and universal design principles, and then learning process and adaptations were addressed in terms of whether they were meeting needs of all children. It can be stated that the program is generally compatible with the principles of early intervention, and is also sensitive to meeting the needs of all children.
\end{abstract}

Keywords:

Early intervention, principles of early intervention, needs of all children

\section{Introduction}

Neuroscience and many research studies have produced results which prove that early years of life are critical years with opportunities not to be missed. The basic functions of the brain and therefore of human development form in these years. From this point of view, having all children including children with developmental sensitivity benefit the early years with quality interventions should be the basic philosophy of countries' care and education policies (Fox, Lozoff, Leavitt, Barr, Stadtler, \& White-Traut, 1999; Guralnick, 2004; Tierney, Nelson III, 2009; Zigler, \& Styfco, 2004).
Nowadays, early intervention is not considered as a narrow term describing an innate developmental risk. Developmental risks may include prenatal risks, birth conditions, parental characteristics, or some subsequent environmental risks. When addressed in this broader context, it can be seen as all the interventions that can help children reach their developmental potential which comes at birth to the highest level possible (Guralnick, 2004; Shonkoff, \& Jack, 2000). Early education policies of countries for infants and toddlers infants and toddlers can be considered as early intervention services. Interventions of early childhood development worldwide are addressed in this context (Kağıtçıbaşı, 2010).

\footnotetext{
${ }^{1}$ Ph.D., Gazi University, Faculty of Education, Department of Primary Education, Division of Early Childhood Education, Ankara TURKEY. e-mail: navcister@gmail.com

${ }^{2}$ MA., Gazi University, Graduate School of Educational Sciences, Child Development and Education, Ankara, TURKEY. e-mail: mugekunt149@gmail.com
} 
Early education programs, which offer rich stimulus enviromentsin the early years, prepare opportunities for development and progress for all children, with or without deprivation. An early education program in line with the basic characteristics of early years and early intervention principles can also be used for children with developmental risks. In recent years, philosophies such as "inclusiveness" (UNESCO, 2009) and "universal design for learning" (Conn-Powers, Frazeur Cross, Krider Traub, \& HutterPishgahi, 2006; Parette, \& Blum, 2014), which have begun to be expressed more all over the world, require education and intervention programs to be responsive to the needs of all children.

The concept of inclusive education is based on an understanding of respecting diversity such as gender, nationality, race, language, social background, the level of educational achievement, and special needs (UNESCO, 2009). Universal design for early learning refers to adapting the program to meet the individual needs of all children, rather than creating a special program. Other aspects of the universal design philosophy are that the educational environment is accessible physically, socially, and emotionally. In early childhood, there are components of multiple means of representation, expression, and engagement related to the universal design. Multiple means of representation suggest that individuals need a variety of ways to gain knowledge and experience. In the early childhood education; there are a lot of materials and programs which provide a lot of ways for expression and several processes to gain knowledge which provides multiple means of representation including vision, hearing, and touching. Multiple means of expression, on the other hand, includes providing various opportunities for the children to demonstrate what they know. Multiple means of engagement suggest that engagement in the early childhood is based on children's interests and it provides necessary motivation. It emphasizes that children can participate in activities at a level appropriate to their developmental characteristics. In brief, universal design in early childhood focuses on creating appropriate environments and education programs that will unlock the potential development of children and meet the developmental needs of all children in the classroom (CAST, 2011; ConnPowers, Frazeur Cross, Krider Traub, \& Hutter-Pishgahi, 2006).

Making an early childhood education program, which meets the developmental needs of all children, have multiple ways of strategies, materials, engagement, and ways of expression is an important issue regarding the quality of the early childhood services. When the education programs covering the early years in our country are examined, it is seen that there is "Infant Toddler Program," which was prepared by MoNE for the early education of children under the age of three and was initiated in the 2013-2014 academic year. MoNE 2013 Infant Toddler Program was prepared taking into account the General Objectives of Turkish National Education, General Objectives of Preschool Education, and Basic Principles which are included in the Basic Law of National Education No. 1739 , and it was developed to ensure that by rich learning experiences children can grow in a healthy way, they can rich the highest level of development, and they can be provided with health, care, and nutrition support in appropriate ways.

It is emphasized by the MoNE and the Ministry of Family and Social Policy, General Directorate of Child Services, that the program should be used in all institutions that provide services to children in the $0-3$ age group, and that families should benefit from this material. When the international literature is examined, it is seen that philosophies of being more inclusive and the fulfillment of the needs of all children, particularly after the 2000s, are reflected in early childhood education programs. It has been wondered whether the early childhood education program prepared by MoNE in our country reflects these educational philosophies in which the high benefit of children is taken into consideration. Moreover, it is also believed that the examination of this program, which serves all children who benefit from institutional services under the age of three, may contribute to the qualitative development of the program and thus to the education and care services provided to childreninfants and toddlers. 


\section{Purpose}

The purpose of this case study is to describe the basic principles of early intervention and the approach of the Infant and Toddler Program to meet needs of all children.

\section{Research questions}

1. How is the approach of the program to reflect the principles of universal design for learning?

2. Does the program fit the developmental characteristics of children aged 0-36 months? 3. How is the program's approach to family involvement?

4. How is the program's approach to partnership?

\section{Method}

\section{Research Model}

This study is a qualitative case study aimed at examining the education program for children aged 0-36 months regarding early intervention principles (Creswell, 2013; Glesne, 2013; Merriam, 2013). A case study is a qualitative approach in which the investigator examines in-depth and thoroughly a current situation in real life using various sources of information (Creswell, 2013).

\section{Study Material}

In qualitative research, documents, and observations, as well as interviews and observations, are the main sources of information. The study material is the MoNE 2013 Infant and Toddler Program. In this scope, the study materials consisted of Infant and Toddler Program Guidelines and Activity Book for Children, Educator's Guidelines for Parent Education and Parenting Guidelines and Health, Care, and Nutrition of $0-36$ Month Old Children Booklet.

\section{Data Collection and Analysis}

In the study, "content analysis," technique for collecting and analyzing text content, was used. With this technique, the data can be identified, and the hard-to-recognize sides can be revealed in the texts. Forming a conceptual framework while interpreting the data with the content analysis is critical in making readers understand the data and ensuring the validity and reliability of the study. Moreover, the main purpose of the content analysis is to deliver the concepts and relationships that can clarify the obtained data. With this point in question, to conduct content analysis, it is necessary to follow some steps. These steps are coding data, finding categories (themes), organizing codes and categories, and identifying and interpreting the data (Merriam, 2013; Neuman, 2010). However, in this study, the categories and codes were created at the beginning of the analysis with the search of the literature.

Four basic dimensions were developed which were universal design for the learning, individual/developmental appropriateness, working with the family (empowering parenting skills, family as a source of information and parent involvement in organizational processes), and teamwork and then categories and codes related to these dimensions were identified. In qualitative research, different approaches are proposed for validity and reliability (Merriam, 2013). One of them is called researcher triangulation (Creswell, 2013). Triangulation technique was used in this research also. For this purpose, the study materials were evaluated separately by the first and second author in accordance with the determined categories and codes. Instead of calculating a reliability score (Miles \& Huberman, 1994) at this stage, the consensus was reached on differences of opinion. In Table 1, categories, codes, and study materials examined for each category are given.

\section{Results}

In this section, the MoNE's 2013 Infant and Toddler Program was examined regarding early intervention principles. Six categories and 19 codes were determined at the beginning of the research with the literature review; then the findings were revealed and interpreted according to these categories and codes. The findings were interpreted under the headings of individual/ developmental appropriateness and universal design, working with the family, and partnership. 
Individual Developmental Appropriateness and Universal Design for Learning

Materials of MoNE Infant and Toddler Program were evaluated according to the categories of universal design for learning and individual developmental appropriateness. The findings are as follows. Table 2 contains the Review of the Infant and Toddler Program regarding the Universal Design for Learning Category.

In this program, which was developed to provide children under the age of three with healthy growing up through rich learning experiences, to maximize their development, and to support their health, care and nourishment in an appropriate way, 15 general characteristics were defined however only six of them could be associated with the principles of universal design for learning. It is expected regarding universal design that there is an emphasis on diversity in the learning process, adaptation and explanation sections in the direction of the general characteristics of the program, it can be stated that only the adaptation section includes extra arrangements for children with special needs. For example, in the adaptation section, the expression of "Adult moves a brightly colored object within sight of a baby with special needs or low vision. The baby should try to track these objects up to a 180-degree angle. If the baby is not tracking, larger objects can be used at a closer distance." is thought to reflect the multiple means of representation and engagement of universal design.

However, in the learning process and explanations section, it is thought that there is not any emphasis on multiple means of representation, expression, or engagement. Moreover, it can be said that there is not any condition to reflect the multiple means of expression in the general characteristics of the program. The code of practice consists of planning, learning environment, daily schedule, activity plan, implementation and evaluation sections. It is identified that there are more discourses to reflect the multiple means of expressions rather than multiple means of representation is expected to take place more in these sections. For example, the emphasis on the use of portfolios in getting to know and evaluating the child is thought to reflect the multiple means of expression.

When the developmental areas are examined, it is determined that this section contains statements which can be considered to reflect the multiple means of representation, expression, and engagement. The following sentence which takes place in the cognitive development area that "The social context and adults have an important role to play in maximizing the progress to take place in this process. Families and educators should prepare a stimulus rich environment, taking into account the level of development of the baby and provide a wealth of experience." might be an example of multiple means of representation. In the points to be considered in supporting children with special needs, it is identified that there are sentences which specifically emphasize multiple means of expression. As an example of the multiple means of expression, the following phrase can be pointed out that is "Let the baby touch your face and feel your mouth's movements while you talk." in the field of language development of supporting children with visual impairments.

An Evaluation of Parenting Guidelines regarding Universal Design for Learning and Individual / Developmental Appropriateness Category

In the development cards section of parenting guidelines, activities related to the areas of motor, cognitive, language and socialemotional development and activities which the individuals who are responsible for the care of babies/children can utilize are available. There is a total of $\mathbf{3 4}$ activities in these fields of which ten are related to motor development, nine are related to cognitive development, nine are related to language development and six related to social- emotional development. Each activity is organized according to the month groups that would be an example of different developmental periods. It was also observed that most of the activities involved included supporting only a single learning outcome.

In contrast to the program's activity book, it was determined that there was no adaptation for babies/children with special needs in these activities which were pre- 
pared for supporting families and individuals who are responsible for the care of the baby/child. For this reason, it can be said that the activities on development cards do not represent the three components of universal design. Also, there are some differences in the indicators of the activities in this section compared to the indicators in the program guidelines. For example, in the activity for the 25th month regarding the motor development, the indicator that is "Let your child put both feet at each step and go down the steps without assistance" is included in the 22-24 months in the program guidelines. However, when it is considered that these activities are supposed to be supportive, it can be said that the presentation of the previous period's indicator in the next period activity may be effective for reinforcing the development of the child. On the other hand, the indicator that is "the ability to pull a toy which can be pulled and pushed" which takes place in 13-15-month motor development is included in the 22-24 month indicators of Infant and Toddler Program Guidelines. According to Ankara Developmental Screening Inventory, Denver II Developmental Screening Inventory, and Gazi Early Childhood Development Assessment Tool, this skill appears to be in the section of 13-15 months (Savaşır, Sezgin \& Erol, 2005; Temel, Ersoy, Avcı \& Turla, 2005; Yalaz, Anlar \& Bayoğlu, 2011). In the activity, the indicator includes appropriate support for children between the ages of 13 and 15 months, but it is found that the two documents differ within the same program.

An Evaluation of the 0-36-Month-Old Activity Book regarding Universal Design and Individual / Developmental Appropriateness Category

There is a total of 66 games and learning activities in the activity book of which 23 are for 1-12 months, 20 are for 13-24 months, and 23 are for 25-36 months. It can be inferred that all of the games are based on the philosophy of developmental appropriateness and the games are for supporting the play development indicators. When the games are examined from goal-learning process relation point of view, it is considered that some of the developmental indica- tors in some games are not supported by the learning process. The second issue related to the activity indicator alignment is that some of the indicators are included in the play, but they do not include appropriate intervention-support. For example, in the area of social-emotional development in the "Touch Carpet" game which targets 7.2. Enjoys listening to the music indicator, there is only one statement that is "... help the baby take a step according to the rhythm of the music playing." This statement is not seen as a kind of intervention to support the indicator of "enjoys listening to music."

It can be said that the games in the activity book are sensitive to the basic needs of children under three years of age. It is seen that emphasis is given to drawing attention to the games, using play environment/ instructions, safety rules, toys, and materials appropriate to baby's / child's physical, cognitive, linguistic, social, and emotional characteristics. Also, it is determined that encouraging/ promoting and reinforcing instructions that are important in children's behavior / skill acquisition/ development are emphasized in all activities.

In some activities, it is determined that a plurality of non-overlapping indicators is taken together. This situation has resulted in the development of some stages and a long activity as the displayed indicators require separate activities. It may be said that it is not possible and efficient to play a long and multi-part game at once, considering the attention periods and other basic needs of children under three years age. The game we are playing together (9th month) is an example of this situation.

Plan a play time with the family members whom the baby knows and is less familiar with (parent, grandmother, grandfather, uncle, aunt, etc.). Sit together in the middle of the room forming a circle. Give the baby a chance to play with her / his toys, and play together by rolling the ball, putting cubes on top of each other, pushing the car. From time to time request the toy the baby is holding and wait for her/him to give it to someone (Gives the object in hand when requested). Say "Now give this toy to ..." and let the baby look at the person whose name is spoken (When a person or object the baby knows is 
asked, turns her I his head to look for them). Check whether the baby is embarrassed when confronted with someone she/he does not know (Is embarrassed by people she/he does not know). Talk to the baby to look at you and support her/him to respond with different voices (Responds by making different voices to the person speaking to her/him).

In this section, the game is changing: Ask the baby to take the toys on furniture such as sofas, couches, and coffee tables (With one hand holding takes an object on ground with the other hand).

To get a toy encourage the baby to stand up by holding the furniture (Clings to the furniture to stand up). Check if she/he reacts by making a noise when she/he is blocked (Responds by making noise when she/he is blocked). Encourage to get over the obstacle and help when necessary (MEB, 2013).

When the activities are examined regarding multiple means of representation, expression, and engagement (universal design) appropriate to the individual needs of infants and children;

- On the page of each activity, there is the heading of adaptation. However, there are not any adaptations in $\mathbf{2 4}$ activities,

- Variety in adaptations for infants and toddlers with special needs are not represented by all the components of the universal design (multiple means of representation, expression, and engagement) as emphasized in the literature,

- It is thought that adaptations are approached with the difference point of view rather than diversity philosophy (e.g., $R e$ member that you need to reduce the distance between the tower and the throwing line when necessary for a child with special needs).

An Evaluation of the Health, Care, and Nutrition Booklet for 0-36-Month-old Children regarding Individual / Developmental Appropriateness Category

The booklet which starts with the following statement that "It is the responsibility of caregivers and educators to ensure that during 0-36 month process children who are separated from their families in institutional care are welcomed correctly and safely... this guidebook is designed to provide them with basic information and to obtain practical information on care, health, and nutrition," was examined regarding the content by taking into consideration the aim and target population. In this direction, this material, which carries the aim to inform the caregivers and educators in support of increasing the quality of life of children, was conducted according to the codes of Reflecting Basic Needs of the Age and Drawing Attention to the Individual Differences which take place in the "Individual / Developmental Appropriateness" category.

The booklet consists of physical characteristics of newborns, babies, and toddlers, childcare practices at 0-36 months, child health care and practices at 0-36 months, and nutrition at 0-36 months. The Ageappropriate Development Features Supporting code in this category was left out because it did not directly match the purpose of the booklet. It can be said that the material is sensitive regarding reflecting the age's basic needs and attention to individual differences.

\section{Working with the Family}

The IFSEG - Educator's Guidelines for Parent Education and Parenting Guidelines were examined for the working with the family principle, which includes the categories of the family as a source of information, the efforts to empower parenting skills, and including families in the institutional processes. The findings are as follows. Table 3 contains An Analysis of the Infanta and Toddler Program Educator's Guidelines for Parent Education regarding Working with the Family Principle. 
Table 1.

Categories and Codes

\begin{tabular}{|c|c|c|}
\hline Categories & Codes & Materials Examined \\
\hline $\begin{array}{l}\text { 1. Universal Design for } \\
\text { Learning (CAST, 2011; } \\
\text { Parette \& Blum, 2014) }\end{array}$ & $\begin{array}{l}\text { 1.1. Multiple Means of Representation } \\
\text { 1.2. Multiple Means of Expression } \\
\text { 1.3. Multiple Means of Engagement }\end{array}$ & $\begin{array}{l}\text { Infant and Toddler Program } \\
\text { Guidelines, } \\
\text { Parenting Guidelines, } \\
\text { Activity Book for 0-36-Month- } \\
\text { Old Children }\end{array}$ \\
\hline $\begin{array}{l}\text { 2. Individual / Develop- } \\
\text { mental Appropriateness } \\
\text { (Guralnick, 2005) }\end{array}$ & $\begin{array}{l}\text { 2.1. Reflecting Basic Needs of Age } \\
\text { 2.2. Supporting Age-Appropriate De- } \\
\text { velopmental Characteristics } \\
\text { 2.3. Attention to Individual Differences }\end{array}$ & $\begin{array}{l}\text { Parenting Guidelines, } \\
\text { Activity Book for 0-36 Month- } \\
\text { Old Children, } \\
\text { Health, Care, and Nutrition } \\
\text { Booklet for 0-36 Month-Old } \\
\text { Children }\end{array}$ \\
\hline
\end{tabular}

3.1. Home Environment Arrangements to Support the Child's Develop-

3. Empowerment Studies ment

of Parenting Skills (Epstein, 2000)

3.2. Studies to Increase Knowledge of Families about Raising a Child

Educator's Guidelines for Parent Education

Parenting Guidelines

3.3. Learning at Home

3.4. Communication with the Family

4. Family as a Source of Information
4.1. General Information

4.2. Information with the Purpose of Evaluation
Educator' s Guidelines for Parent Education

5.1. Family Involvement in Decision Making Processes

5. Involving Families in the Institutional Processes (Epstein, 2000)

5.2. Volunteering

5.3. Participation in Classroom Activities

6.1. The Individual who is Responsible for the Education

6. Partnership

6.2. The Role of the Family

6.3. The Role of the Society

6.4. Other Professionals

Educator' s Guidelines for Parent Education
Parenting Guidelines

Educator's Guidelines for Parent Education

\section{Table 2.}

Evaluation of the Infant and Toddler Program Guidelines regarding the Universal Design for Learning Category

\begin{tabular}{|c|c|c|c|c|}
\hline & \multicolumn{4}{|c|}{ Universal Design for Learning } \\
\hline & $\begin{array}{l}\text { Multiple } \\
\text { Represent }\end{array}$ & $\begin{array}{l}\text { Means of } \\
\text { ation }\end{array}$ & $\begin{array}{l}\text { Multiple Means of } \\
\text { Expression }\end{array}$ & $\begin{array}{l}\text { Multiple Means of } \\
\text { Engagement }\end{array}$ \\
\hline $\begin{array}{l}\text { General Characteristics of the } \\
\text { Program ( } 6 \text { items) }\end{array}$ & \multicolumn{2}{|r|}{4} & 0 & 3 \\
\hline $\begin{array}{l}\text { Principles of Implementation } \\
\text { (6 items) }\end{array}$ & \multicolumn{2}{|r|}{1} & 4 & 2 \\
\hline $\begin{array}{l}\text { Developmental Areas (Indicators) } \\
\text { (4 items) }\end{array}$ & \multicolumn{2}{|r|}{4} & 4 & 4 \\
\hline Points to Consider in Supporting & \multirow{2}{*}{\multicolumn{2}{|c|}{0}} & \multirow[b]{2}{*}{7} & \multirow[b]{2}{*}{0} \\
\hline $\begin{array}{l}\text { Children with Special Needs } \\
\text { ( } 7 \text { items) }\end{array}$ & & & & \\
\hline
\end{tabular}


Table 3.

Evaluation of Educator's Guidelines for Parent Education regarding Working with the Family Principle

\begin{tabular}{|c|c|c|c|c|c|c|c|c|c|}
\hline & \multicolumn{2}{|c|}{$\begin{array}{l}\text { Family as a Source of Infor- } \\
\text { mation }\end{array}$} & \multicolumn{4}{|c|}{ Efforts to Empower Parenting Skills } & \multicolumn{3}{|c|}{$\begin{array}{l}\text { Including Families in the Institutional } \\
\text { Processes }\end{array}$} \\
\hline & $\begin{array}{l}\text { General } \\
\text { information }\end{array}$ & $\begin{array}{l}\text { Information } \\
\text { with the } \\
\text { Purpose of } \\
\text { Evaluation }\end{array}$ & $\begin{array}{l}\text { Home Envi- } \\
\text { ronment } \\
\text { Arrange- } \\
\text { ments to } \\
\text { Support } \\
\text { Child's } \\
\text { Develop- } \\
\text { ment } \\
\end{array}$ & $\begin{array}{l}\text { Practices to } \\
\text { Increase } \\
\text { Knowledge of } \\
\text { Families about } \\
\text { Raising a Child }\end{array}$ & $\begin{array}{l}\text { Learning } \\
\text { at Home }\end{array}$ & $\begin{array}{l}\text { Communi- } \\
\text { cation with } \\
\text { the Family }\end{array}$ & $\begin{array}{l}\text { Family } \\
\text { Involvement } \\
\text { in Decision } \\
\text { Making } \\
\text { Processes }\end{array}$ & $\begin{array}{l}\text { Volunteer- } \\
\text { ing }\end{array}$ & $\begin{array}{l}\text { Engage- } \\
\text { ment in In- } \\
\text { Class Activi- } \\
\text { ties }\end{array}$ \\
\hline Practices (9 sessions) & 0 & 0 & 6 & 9 & 0 & 1 & 0 & 0 & 0 \\
\hline $\begin{array}{l}\text { Family Communication Activi- } \\
\text { ties } \\
\text { (14 activities) }\end{array}$ & 4 & 2 & 1 & 0 & 1 & 14 & 1 & 0 & 1 \\
\hline $\begin{array}{l}\text { Engagement of Family in } \\
\text { Education Activities }\end{array}$ & 0 & 0 & 0 & 0 & 0 & 0 & 0 & 0 & 1 \\
\hline Individual Interviews & 1 & 1 & 0 & 1 & 0 & 1 & 0 & 0 & 0 \\
\hline Forms & 1 & 0 & 0 & 0 & 0 & 1 & 0 & 0 & 1 \\
\hline
\end{tabular}


The sample sessions for family education in the Educator's Guidelines for Parent Education consist of 9 sections. These are; Session 1: "The Importance of Institutional Education and Expectations from the Families," Session 2: "Basic Trust and Attachment," Session 3: "Parent Attitudes," Session 4: "Positive Discipline," Session 5: "Effective Communication," Session 6: "Play and Toys," Session 7: " Children's Prepare Books," Session 8: "Sensory Training," and Session 9: "Creating Awareness Towards Individuals with Special Needs." These sessions have been examined regarding the categories of families as a source of information, practices to empower parenting skills, and involvement of families in institutional processes. In all sessions, it is seen that practices take place to increase knowledge of parents about child raising which is a practice to empower parenting skills; whereas communication with the family is only included in the first session which is namely "The importance, purpose of the institutional education and expectations from the families," It can also be seen that home environment arrangements with the purpose of supporting child development do not take place in sessions of "Importance, Purpose of Institutional Education and Expectations from the Families," "Basic Trust and Attachment," and "Creating Awareness for Individuals with Special Needs," however these arrangements take place in other sessions. As a result of the evaluation, it is determined that categories of families as a source of information, and involvement of families in institutional processes are not addressed in all of the nine sessions.

There are 14 activities about family communication in Educator's Guidelines for Parent Education. These activities were also examined regarding the categories of the family as a source of information, efforts to empower parenting skills, and involving families in institutional processes. In all activities, a practice of empowering parenting skills which is communication with the family takes place, while only in bulletins activity at home environment arrangements with the purpose of supporting child's development take place. Practices to increase knowledge of parents about child raising is not found in any of the activities. When the activities are examined in terms of the category of family as a source of information, it is seen that communications with letters with the purpose of general information, meetings, the times of arrivals and departures, wish boxes, and development files (portfolio) are used; however, for gaining information with the purpose of evaluation communications with letters and development files are used.
Family involvement in the decision-making process in including families in the institutional processes is only encountered in meeting activity, while it is only encountered in institutional visits in involvement in in-class activities.

In the examination of the section of the guidelines' Family's Involvement in Education Activities, there is only the topic of involvement in classroom activities related to the involvement of families in institutional processes category. In individual interviews, which consist another part, in the category of the family as a source of information, getting information from the families for general information and the purpose of evaluation are addressed, moreover, in this section which includes communication with the family, practices take place that increases knowledge of parents about child raising.

Forms which are the last part of the guidelines contains "Family education needs assessment form" and "Family involvement preference form." These forms include the general information code from the category of the family as a source of information, and in the category of involving families in the institutional processes, code of involvement in classroom activities take place. Table 4 summarizes the evaluation of Infant and ToddlerProgram Parenting Guidelines regarding the Category of Practices to Empower Parenting Skills.

The Parenting Guidelines includes ten chapters consisting of cleaning for babies and children, baby massage, health, nutrition, forms, play and toys handbook, illustrated children's books booklet, sensory training booklet, awareness booklet for individuals with special needs, and development cards. In the development cards section, there are activities organized in accordance with the development areas and periods to support the parents and the individuals responsible for the care of the infant/toddler. This section was also examined regarding universal design and individual/ developmental appropriateness categories.

This document, which was examined from the perspective of category of practices on empowering parenting skills, shows that under the six sections of above mentioned 10 sections, there are home environment arrangements aimed to support the development of the child, under eight categories there are practices to increase knowledge of families about raising a child, under one category there are arrangements to learn at home, and under two categories there are arrangements to communicate with the family. In this program, in Educator's Guidelines for Parent Education, there are activities for the communication with the family topic which 
include activities to form effective communication bridges from home to school and from school to home about school programs and progress of the child (Avcl, 2010).

The presentation of information to, ideas and materials for families to support the activities of the school environment in the home environment explain home learning (Epstein, 2000). It can be said that there is very little information related to learning at home in materials examined within the program. Considering that the care and education of babies/children between 0-36 months in our country are mostly carried out in the home environment, this can be accepted as the reason why this situation is less frequently included in the program. However, regarding educational institutions for infants ande toddlers, even though education at these institutions are qualified, unless this education given at the schools is supported at home, educational institutions and the programs prepared will not reach their goals.

\section{Table 4.}

An Evaluation of the Infant and Toddler Program Parenting Guidelines regarding the Category of Practices to Empower Parenting Skills

\begin{tabular}{lc}
\hline Practices to Empower Parenting Skills & Frequency \\
\hline Practices to Increase the Knowledge of Families about Raising a Child & 8 \\
Home Environment Arrangements to Support Child Development & 6 \\
Communication with the Family & 2 \\
Learning at Home & 1 \\
\hline
\end{tabular}

\section{Partnership}

Finally, the Infant and Toddler Program Educator' s for Parent Education and Parenting Guidelines were examined regarding teamwork category. The findings are as follows.

In this study, the category of parnership is addressed to include the individual who is responsible for the education, the role of the family, the role of the society, and other professionals. Since the basic principle and understanding of the program are emphasized in the guidebook of "Infant and Toddler Program Guidelines" the partnership understanding is evaluated based on these guidelines. In the direction of the evaluations;

- The way of expression addresses the educator and the family.

- Frequently, collaborative role of the family in the education of the child is emphasized. The parenting guidelines can be shown as an important material which proves this emphasis.

- When examined regarding professional collaboration, there is not any clear reference to other professionals and collaboration. The Word "adult" is preferred for sharing the educational care responsibility. The only proof for professional collaboration may be the suggestion to refer to the hospital when confronted with a developmental issue.

- There is not any emphasis on the collaboration with the society.

\section{Conclusion}

Today, early childhood development, which includes not only education but also care, covers the meeting basic needs of health, nutrition, and socialemotional, motor, language, and cognitive development. In Turkey, the MoNE's 2013 Preschool Education Program which was prepared by "Empowering Preschool Education" Project, emphasizes providing early intervention services with the understanding of scientific care and education for children under the age of three. The history of our country's program for children under the age of three goes back to the year 1996. However, it can be said that there was not any initiative until 2013 for implementation, generalization, and updating. With this project, the Education Program for 0-36Month-Old Children was updated, and it was proposed by MoNE to be implemented by 2013 .

In this study, which qualitatively examined Infant and Toddler Program in terms of basic principles of early intervention and the understanding of meeting needs of all children (universal design), in the scope of the program Infant and Toddler Program Guidelines, Activity Book, and Health, Care, and Nutrition Booklet were examined in terms of early intervention's categories of universal design, individual / developmental appropriateness, empowering parenting skills, family as a source of information, involving families in institutional processes, and partenership. The results are interpreted under the titles of universal design for learning, 
individual/developmental appropriateness, working with the family, and partnership.

The program guidelines, activity book for 0-36month-old children, and the parenting guidelines development cards sections which are examined regarding the category of universal design for learning are thought to reflect some of the universal design's characteristics. For example, including adaptation section in the program guidelines is evidence that the program contains extra arrangements for children with special needs. It may be said that this feature represents universal design. Moreover, it was seen that in the section of indicators which are separated according to developmental areas multiple means are included showing that this section also covers universal design. However, when the general characteristics of the program are examined, it is thought that only the adaptation section reflects the diversity, the learning process, and the explanations section do not include diversity. The fact that the learning process does not involve diversity shows that it is far from universal design. For this reason, it is expected that the learning process can meet the needs of all children (CAST, 2011).

In the activity book, the title of the adaptation is included in each activity page, but it is determined that there are not any adaptations under 24 activities of 66 activities in total. It is thought that adaptations in the activity book may be insufficient at the point of meeting all children's needs, but it is considered to be an important initiative regarding making it a part of the program for the first time. The fact that a country program serving early childhood education for all children is designed to include multiple means of representation, expression, and engagement, must be a priority for children to have equal educational and developmental opportunities which are included in national and international texts (CAST, 2011; United Nation's Children's Rights Committee [UNCRC] 2009). This is possible, as emphasized above, by focusing on the diversity of the learning process and program's all aspects (CAST, 2011).

In the activities included in the Parenting Guidelines Development Cards, it is seen that contrary to the activity book there are not any adaptations for infants/childrens with special needs. For this reason, it can be said that the activities on the development cards do not fully represent the three components of the universal design (CAST, 2011; Conn-Powers, Frazeur Cross, Krider Traub, \& Hutter-Pishgahi, 2006).

Even though the materials examined according to the category of universal design for learning to seem to be appropriate to the universal design as a philosophy, it is thought that three components are not addressed adequately in the activity book. This can be seen as a problem regarding the right to benefit from the education which is appropriate for all children's characteristics and abilities (United Nations Convention on the Rights of the Children [UN CRC], 1995).

It can be said that the activity book for 0-36month-old children, Parenting Guidelines development cards section and Health, Care, and Nutrition for 0-36 Month Old Children Booklet, which is examined regarding individual/developmental appropriateness category, contain information about meeting basic needs in early periods mentioned in the literature. There is a total of 66 games in the activity book of which 23 are for 1-12month-olds, 20 are for 13-24-month-olds, and 23 are for 25-36-month-olds. All of the games are based on the developmental appropriateness principle which is in accordance with the program's philosophy, games to support developmental indicators were developed.

0-36 months' period is one of the important periods in which the development is the most rapid in human life, and an appropriate early intervention should contain two main components. The first of them is to form a home environment which has more stimuli and the second one is to provide positive parental attitudes (Kağıtçıbaşı, 2010). These two basic components of early intervention can be seen as a guide to how to follow the path of early intervention in our country (Kağıtçıbaşı, 2010). Accordingly, it is considered that the activities aimed at supporting the families within the framework of the education program and increasing the environmental stimuli in the home environment will contribute to the development of infants and toddlers.

It is observed that the information shared in health, care, and nutrition of children aged 0-36 months include the basic needs of the very young age, and the individually diverse situations are included in the nutrition section in particular. These two characteristics of the material are important and satisfactory regarding including principles of early intervention focusing on the basic needs and individualization (Berlin, Brooks-Gunn, McCarton, \& McCormick, 2010, Guralnick, 2005).

According to working with the families' principle, Educator's Guidelines for Parent Education, which was examined in terms of Epstein's (2000) family involvement levels such as family as a source of information, studies to empower parenting skills, and involving families in the institutional processes, 
include especially increasing knowledge of families about child raising and communication with the family, however it partially contains home arrangements to support child's development. Also, it is determined that there are family involvement and collaboration with family. However, there are not volunteering practices at all. Informing families and supporting their child's development at home are among the basic methods of early support programs (Ertem \& Özdemir, 2005). The MoNE's 2013 Infant and Toddler Program is thought to reflect an understanding of the importance of family involvement in the early years since it includes family involvement in all the dimensions but the volunteering. Family involvement, of which the basic philosophy can be based on bio-ecological theory (Bronfenbrenner cited by Berk, 2013; Original, 2015), requires that all individuals and environments which the child interacts are organized to support the optimal development of children (Driessen, Smit, \& Sleegers, 2005; Epstein, 1995, 2000, 2001, 2005, 2008; Epstein \& Sanders, 2006).

The Parenting Guidelines, which was designed to inform and support families and individuals responsible for infants/toddlers about cleaning for babies and children, baby massage, health, and nutrition, was evaluated regarding four codes in the category of empowering parenting skills. Development Cards which takes place at the last part of the same document was evaluated regarding universal design and individual/developmental appropriateness categories. In the category of empowering parenting skills, home environment arrangements to support child development and studies to increase knowledge of parents about child raising take place; however, communication with family (two activities) and learning at home (one activity) have a few activities comparatively. Home-based education programs are critical in the development of children with special needs and at risk, especially during the 0-36-month period. During infancy support, should be provided by primary caregivers and home environment should be developmentally supported (Batu \& Yükselen, 2015).

When the program is evaluated regarding the partnership category, it can be said that the role of the individual responsible for the education and the family is included in the program but that the program is limited regarding the other professionals and the role of the community is not included at all. The Early Intervention is the phase in which the collaboration is most needed in the integration of services. Despite universal acceptance of the importance of the relationship based, family based early intervention and teamwork based on the collaborative relationship in special education, it is emphasized in the literature that it is not easy to form a team based on collaborative relationships (Epstein, 1995).

As a result, this study which was conducted to describe the Infant and Toddler Program in terms of being inclusive that includes basic principles of early intervention and its approach to meet needs of all children, it is thought that the program is philosophically appropriate to the universal design for learning principle however it does not address all three components of the universal design. Regarding individual developmental appropriateness, emphasizing that the basic needs of young children may particularly vary individually, reflects the program's appropriateness regarding the principles of early intervention. However, it can be said that some of the activities' learning process is long and the relationship of the indicator learning process is weak. In the program, an understanding of the importance of family involvement in early years is observed, but home environment arrangements aimed at supporting the development of the child are only partially found. It can be said that in terms of the partnership principle only the role of the educator and the family are included, the issue of society however and other professionals are inadequately addressed. Based on the results of the research, the following suggestions can be made:

1. While reviewing MoNE's 2013 Infant and Toddler Program, a common philosophy can be adopted in all the materials (general characteristics of the program can be common in all materials).

2. The program can be reorganized regarding multiple means of representation, expression, and engagement of universal design for learning.

3. The program's partnership philosophy can be widened as the family, professional, and community collaboration.

4. Diversity in early intervention programs for children under the age of three can be increased.

\section{Limitations:}

1. As a means of collecting data, only a document review was conducted. Also, the data triangulation could be done by interviewing the educators who were implementing the program to the field.

2. A "universal design" framework was used for implementations which include all children as an early intervention principle. Another framework can be addressed.

3. The two researchers reached agreement on the reliability of the study. The opinions of an independent researcher could be consulted. 


\section{References}

Avcı, N. (2010). Okul Öncesi Eğitimde Aile Katılımı [Family involvement during preschool education]. In R. Zembat, Okul Öncesinde Özel Öğretim Yöntemleri [Special Instructional Methods in Preschool]. Anı Yayıncılık.

Batu, S. E. \& Yükselen, A. (2015). Erken çocukluk özel eğitim ve kaynaştırma uygulamalarında genel prensipler [General principles in early childhood special education and mainstreaming practices]. In N. Metin \& A. Yükselen (Eds.) Özel gereksinimli çocuklar ve kaynaştırma [Children with special needs and mainstreaming] $\mathrm{pp}$. 329-384. Ankara: Hedef.

Berk, L. E. (2013). Bebekler ve çocuklar [Babies and children]. N. Işıkoğlu Erdoğan, Trans.). Ankara: Nobel.

Berlin, L. J., Brooks-Gunn, J., McCarton, C. \& McCormick, M. (2010). The Effectiveness of Early Intervention: Examining Risk Factors and Pathways to Enhanced Development. In M. A. Feldman, Early Intervention: Them Essential Readings (pp. 134-152). MA: Blackwell Publishing Ltd.

CAST (2011). Universal Design for Learning Guidelines version 2.0. Wakefield, MA: Author.

Conn-Powers, M., Frazeur Cross, A., Krider Traub, E. ve Hutter-Pishgahi, L. (2006). The Universal Design of Early Education: Moving Forward for All Children. Beyond the Journal • Young Children on the Web, 1-9.

Creswell, J. W. (2013). Nitel araştırma yöntemleri. [quantitative, qualitative and mixed approaches] (M. Bütün \& S. B. Demir, Trans.) Ankara: Siyasal.

Driessen, G., Smit, F., \& Sleegers, P. (2005). Parental involvement and educational achievement. British educational research journal, 31(4), 509-532.

Epstein, J. L. (1995). School/family/community partnerships, Phi Delta Kappan, 76(9) 701-713.

Epstein, J. L. (2000). Epstein's six types of parent involvement, Johns Hopkins University retrieved from http://www.csos.jhu.edu/p2000/sixtypes.htm

Epstein, J. L. (2001). Building bridges of home, school, and community: The importance of design. Journal of education for students placed at risk, 6(1-2), 161-168.

Epstein, J. L. (2005). Links in a professional development chain: Preservice and inservice education for effective programs of school, family, and community partnerships. The New Educator, 1(2), 125-141.

Epstein, J. L. (2008). Improving family and community involvement in secondary schools. Education Digest, 73(6), 9.

Epstein, J. L., \& Sanders, M. G. (2006). Prospects for change: Preparing educators for school, family, and community partnerships. Peabody Journal of Education, 81(2), 81-120.

Epstein, J.L. (2000). Epstein's Six Types of Parent Involvement, Johns Hopkins University, March 23, 2014, retrieved from www.csos.jhu.edu/p2000/sixtypes.htm.

Ertem, i. Ö. \& Özdemir, S. i. (2005). Gelişimi destekleyen yaklaşımlar ve programlar [Approaches and programs which support the development]. In i.Ö. Ertem (Ed.) Gelişimsel Pediatri [Developmental Pediatrics] pp. 451- 587. Ankara: Çocuk Hastalıkları Araştırma Vakfı.

Fox, N. A., Lozoff, B., Leavitt, L. A., Barr, R. G., Stadtler, A. C., \& White-Traut, R. (1999). Discussion. In L. A. Nathan A. Fox, The Role of Early Experience in Infant Development (pp. 292-300). Johnson \& Johnson Pediatric Institute Pediatric Round Table Series: Divison of Johnson \& Johnson Consumer Companies, Inc.

Glesne, C. (2013). Nitel Araştırmaya Giriş [Introduction to Qualitative Research]. Ankara: Anı.

Guralnick, M. J. (2004). Effectiveness of Early Intervention for Vulnerable Children: A Developmental Perspective. In M. A. Feldman, Early Intervention: Them Essential Readings (pp. 9-50). MA: Blackwell Publishing Ltd.

Kağıtçıbaşı, Ç. (2010). Benlik, Aile ve Insan Gelişimi [Personality, Family, and Human Development]. İstanbul: Koç Üniversitesi Yayınları.

Merriam, S.B. (2013). Nitel Araştırma - Desen ve uygulama İçin Bir Rehber [Qualitative Reserach - A Guile for Design and Implementation]. Nobel Yayıncılık.

Miles, M. B. \& Huberman, A. M. (1994). Qualitative data analysis: an expanded sourcebook (2nd ed.). London: Sage.

Özgün, Ö. (2015). Çocuk gelişimi kuramları [Child development theories]. In F. Turan \& A. Yükselen (Ed.), Çocuk gelişimi 1 bebeklik döneminde gelişim [Child development 1 development during infancy] pp. 46-79 Ankara: Hedef.

Savaşır I., Sezgin N. \& Erol N. (2005). Ankara Gelişim Tarama Envanteri El Kitabı, Kayıt Formu ve Değerlendirme-Profilleri. Genişletilmiş Ücüncü Basım (3rd. Edition) Ankara: Rekmay Ltd. Şti. ISBN: 975-95226-1-6. 
Shonkoff, J. P., \& Phillips, D. A. (Eds.). (2000). From neurons to neighborhoods: The science of early childhood development. National Academies Press.

Temel, F., Ersoy, Ö., Avcl, N., \& Turla, A. (2005). Gazi erken çocukluk gelişimi değerlendirme aracı "GEÇDA". Ankara: Rekmay Ltd. Şti.

Tierney, A. L., \& Nelson III, C. A. (2009, November). Brain Development and the Role of Experience in the Early Years. March 23, 2014, retrieved from www.zerotothree.org/reprints.

UNESCO. (2009). Policy Guidelines on Inclusion in Education. 08082012 retrieved from UNESCO: http://unesdoc.unesco.org/images/0017/001778 /177849e.pdf.
United Nations Children's Rights Committee, (1995). Çocuk Haklarına Dair Sözleşme [Agreement on Children's Right]. 27 January 1995 dated and 22184 numbered Offical Journal.

Yalaz, K., Anlar, B., \& Bayoğlu, B. (2011). Denver II Gelişimsel Tarama Testi "Türkiye Standardizasyonu”. Gelişimsel Çocuk Nörolojisi Derneği, Ankara.

Zigler, E., \& Styfco, S. J. (2004). Applying the Findings of Developmental Psychology to Improve Early Childhood Intervention. In M. A. Feldman, Early Intervention: The Essential Readings (pp. 5472). MA: Blackwell Publishing Ltd. 
